\title{
Preparing Pre-service and In-service Teachers to Teach Mathematics and Science Using an Integrated Approach: The Role of a Six-Week Summer Course
}

\author{
Roland G. Pourdavood and Meng Yan \\ Cleveland State University, Cleveland, Ohio, USA \\ https://orcid.org/0000-0003-2777-7867 \\ https://orcid.org/0000-0002-6031-5114
}

\begin{abstract}
Many pre-service and in-service elementary teachers indicate that they have limited content knowledge, pedagogical knowledge, and experience regarding the integrated teaching of mathematics and science. Such limitation puts them in an uncertain and vulnerable situation in terms of planning and instruction. This qualitative, descriptive, and interpretative study examines the experiences of 28 preservice and in-service teachers as they plan and teach during a six-week summer course on integration of mathematics and science instruction for $4^{\text {th }}$ and $5^{\text {th }}$ grades. The research question is: how may a six-week summer course focusing on planning and teaching mathematics and science using an integrated approach enhance teachers' knowledge, experience, and confidence in teaching? Data include participating teachers' reflections on assigned readings, meeting discussions, collaborative planning and teaching, their final papers, and the instructor's field notes. The findings suggest that the exchange of ideas and information along with the instructor's ongoing support provides the teachers with opportunities to become more knowledgeable and confident in integrating mathematics and science. The study also suggests that ongoing professional development and school district administrative support are essential components for sustaining teachers' professional development related to teaching mathematics and science from an integrated perspective.
\end{abstract}

Keywords: collaboration; integration; interdisciplinary; professional development

\section{Introduction}

STEM education (science, technology, engineering, and mathematics) is receiving increasing attention worldwide. The combination of the four disciplines was "a strategic decision made by scientists, technologists, engineers, 
and mathematicians to combine forces and create a stronger political voice" (STEM Task Force Report, 2014, p. 9). Partly due to the current and future actual or perceived shortage of STEM workforce, STEM education is considered as vital in many countries (Caprile, Palmen, Sanz \& Dente, 2015; Charette, 2013; Hopkins, Forgasz, Corrigan \& Panizzon, 2014; Margot \& Kettler, 2019). Policymakers, educators, and business leaders have all emphasized the urgency of promoting STEM skills to meet current and future social and economic challenges (English, 2016; Honey, Pearson \& Schweingruber, 2014; Marginson, Tytler, Freeman, \& Roberts, 2013; Prinsley \& Baranyai, 2015). This responsibility naturally falls on schools as it is critical to the economy that schools produce students who can make great contributions in the fields of STEM. To achieve this goal, a growing number of elementary and secondary schools are integrating STEM curriculum and pedagogy into their classrooms (Margot et al., 2019). The STEM Task Force Report (2014) points out that STEM education is much more than a "convenient integration" of the four disciplines, which "cannot and should not be taught in isolation, just as they do not exist in isolation in the real world or the workforce" (p. 9). English (2017) believes that if well-designed integrated STEM experiences are implemented, it will be very helpful to promote Masters' (2016) recommendations on cultivating students' learning in the 21st century, meeting students' preparation levels, and extending their capacities. Gomez and Albrecht (2013) also advocate the establishment of this kind of education in STEM pedagogy through an interdisciplinary approach, so that students can build connections with the real world and prepare for STEM careers.

There are various definitions of STEM education, among which the definition proposed by Shaughnessy (2013) has been considered the most appropriate (English, 2016), which highlights the mathematics and science disciplines within the STEM space: "STEM education refers to solving problems that draw on concepts and procedures from mathematics and science while incorporating the teamwork and design methodology of engineering and using appropriate technology" (p. 324).

Within STEM education, teaching mathematics and science in an integrated fashion indeed gained widespread support (American Association for the Advancement of Science, 1993; National Council of Teachers of Mathematics, 2000; National Research Council, 1996). Moore, Glancy, Tank, Kersten, Smith, \& Stohlmann (2014) designated a framework including six core principles for quality K-12 STEM education, with the first two as the inclusion of mathematics and science content and student-centered pedagogy. Judith Ramely, director of education and human resources division of the National Science Foundation, also stated that mathematics and science are used as bookends for engineering and technology (Christenson, 2011). Integration of mathematics and science is advocated as a way through which students can develop deeply organized and interconnected knowledge structures (Huntley, 1998).

As with STEM education, there does not exist a shared definition of the integration of mathematics and science. Among the various conceptualizations of integrated mathematics and science by scholars such as Berlin and White (1995), Davison, Miller, and Metheny, (1995), Lederman and Niess (1997), 
Lonning and DeFranco, (1997), and Underhill (1995), Huntley (1998) described a theoretical framework for defining integrated mathematics and science, focusing on the distinctions between intra-disciplinary, interdisciplinary, and integrated curricula. According to Huntley (1998), an intra-disciplinary curriculum refers to the instruction that focuses on one discipline; an interdisciplinary curriculum focuses on the instruction of one discipline, with one or more other disciplines supporting or facilitating content in the first field by establishing relevance or context; whereas an integrated curriculum is one in which instructors explicitly assimilate concepts from multiple disciplines in the teaching process, featured typically by roughly equal attention to two (or more) disciplines. Attendees at the 1967 Cambridge Conference defined five categories to describe the various interactions between mathematics and science, namely, mathematics for the sake of mathematics, mathematics for the sake of science, mathematics and science, science for the sake of mathematics, and science for the sake of science (Education Development Centre, 1969). Expanding upon Lonning et al.'s (1997) model, Huntley (1998) converted these discrete categories into continuous, showing the different levels at which mathematics and science are coordinated in the teaching process on a continuum model (shown in Figure 1). Our conception of the integrated approach in this current study is guided by this framework.

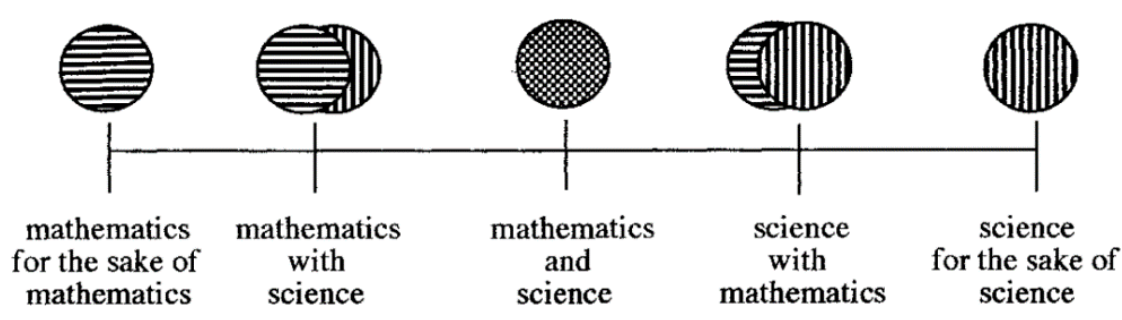

Figure 1

The integrated approach to instruction promotes thinking in terms of relationship, connectedness, and context, thereby helping students form integrated knowledge and experience meaningful learning relevant to real-life (Drake, 2000). Integrated instruction also creates a holistic and multidisciplinary learning experience and provides students with opportunities for crossknowledge analysis, assessment, and creativity (Bossé, Lee, Swinson \& Faulconer, 2010; Furner \& Kumar, 2007; Treacy \& O’Donoghue, 2013). As students experience integrated instruction, critical thinking skills emerge as they address problems from a multidisciplinary perspective. Research provides empirical evidence demonstrating that integration of mathematics and science instruction helps students to enhance their performance in both disciplines and facilitates classroom activities and discussions (Furner et al., 2007; Haigh \& Rehfeld, 1995; Ríordáin, Johnston \& Walshe, 2016). Educators indicate that professional development focusing on providing integrated instruction encourages the application of this approach for instructional purposes (Bossé et al., 2010; Drake, 2000; Treacy et al., 2013). 
To provide in-depth problem solving through the integration of disciplines with real experiences, teachers must be proficient in this unique student-oriented pedagogy. Educators should not only understand their own subject matter but also, they need to be able to create a classroom environment that is engaging and iterative (Margot et al., 2019). However, the reality is that many pre-service and in-service teachers do not have adequate content and pedagogical knowledge, experience, and confidence to implement the integrated approach into their daily classroom instruction (Adams 1998; Babbitt \& Van Vactor, 1993; Ball, 1991; Kruger, 1990). It is important to provide teachers professional development opportunity relative to integration of mathematics and science. However, while the integration of mathematics and science has been widely advocated, it is yet a relatively unexplored area (Pang \& Good, 2000), and this prompted us to explore the experiences of 28 pre-service and in-service teachers in planning and teaching mathematics and science in $4^{\text {th }}$ and $5^{\text {th }}$ grades using an integrated approach during a six-week summer course to answer the research question: How may a six-week summer course focusing on the planning and teaching of mathematics and science using an integrated approach enhance teachers' knowledge, experience, and confidence in teaching?

\section{Review of Literature}

Technological complexities, current learning theories, and classroom dynamics necessitate a new mindset for meaningful integration of science, technology, engineering, and mathematics (STEM). The ideas and activities regarding curriculum, instruction, and learning must be engaging and relevant to our students' real-world experiences (Johnson, Mohr-Schoeder, Moore \& English, 2020; Penprase, 2020). The integration of science and mathematics has long been supported by well-respected academic organizations such as American Association for the Advancement of Science, National Council of Teachers of Mathematics, National Research Council, National Council of Teachers of Mathematics, as well as School Science and Mathematics Association (Czerniak, Weber, Sandmann \& Ahern, 1999), and received increasing attention from educators in recent years. The interrelated nature of science and mathematics, implications for teaching and learning, and the significance of integrating the two disciplines in school education have been explained in different ways as follows:

"It is the union of science, mathematics, and technology that forms the scientific endeavor, and that makes it so successful. Although each of these human enterprises has a character and history of its own, each is dependent on and reinforces the others" (AAAS, 1993, p. 3).

"A coherent curriculum effectively organizes and integrates important mathematical ideas so that students can see how the ideas build on, or connect with, other ideas, thus enabling them to develop new understandings and skills" (NCTM, 2000, p. 15).

"The science program should be coordinated with the mathematics program to enhance student use and understanding of mathematics in the study of science and to improve student understanding of mathematics" (NRC, 1996, p. 214).

"The opportunity for students to experience mathematics in a context is important. Mathematics is used in science, the social sciences, medicine, and commerce. The link between mathematics and science is not only through content but also through process. The processes and content of science can 
inspire an approach to solving problems that applies to the study of mathematics...School mathematics experiences at all levels should include opportunities to learn about mathematics by working on problems arising in contexts outside of mathematics. These connections can be to other subject areas and disciplines as well as to students' daily lives" (NCTM, 2000, pp. 65-66).

Several other investigations provided additional literature on science and mathematics integration, showing evidence of validity and explaining stakeholders' support for the integration (e.g. Berlin \& Lee, 2005; Bossé et al., 2010; Czerniak et al., 1999; Hurley, 2001; Pang et al., 2000; West, VasquezMireles, \& Coker, 2006). Some studies have shown that integrating mathematics and science has a positive effect on students' attitudes and interest in school (Bragow, Gragow, \& Smith, 1995; McComas, 1993) motivation to learn (Guthrie, Wigfield \& VonSecker, 2000), and academic achievement (Hurley, 2001). Furner et al. (2007) are optimistic about improving science and mathematics education through integration, arguing that problem-based learning is an area where mathematics and science could be successfully integrated. There are also reports that teachers, especially pre-service and beginning teachers, generally support the idea of integrating science with mathematics, but they often encounter obstacles when trying to implement it (e.g. Basista \& Mathews, 2002; Frykholm \& Glasson, 2005; Judson, 2013; West et al., 2006). The literature further shows that teachers agree with the concept of integration, but the various stumbling blocks they are faced with have led to quality deficiencies in the implementation (Judson, 2013).

Multiple empirical studies have been conducted in this area in various aspects. A relationship between science and mathematics teaching efficiency of preservice primary school teachers has been identified in a study by Utley, Moseley and Bryant (2005). Their findings suggest that teachers' professional development impacts their attitudes and beliefs towards integration of mathematics and science. Also, research indicates that the methods course has a significant impact on the way teachers teach (Haigh, 1985); therefore, it is important for pre-service teachers to have conceptual understanding of mathematical and scientific ideas (Frykholm et al., 2005).

Koirala and Bowman (2003) did a three-year study of pre-service middle school integrated mathematics and science methods course by observing pre-service teachers of grades 5 to 8 and taking field notes during their visits. Their findings suggest that pre-service teachers are in favour of teaching mathematics and science in an integrated way but tend to be frustrated when they find certain concepts difficult to integrate. The findings also indicate that the integrated course contributed to the improvement of those pre-service teachers' understanding of integration.

Pyke \& Lynch's (2005) study on the preparation of mathematics and science teachers enrolled in an integrated preparatory course for the certification of the National Committee for Professional Teaching Standards. Their findings shows that teachers' collaboration enhances their learning and their mathematics and science disposition. Underbill and his colleagues (e.g., Francis \& Underbill, 1996; 
Underbill, Abdi \& Peters, 1994) also advocate collaboration, suggesting peer collaboration between a teacher with a strong background in mathematics and another in science to integrate mathematics and science.

Margot et al. (2019) did a systematic literature review regarding teachers' perception of STEM integration and education. The findings of their review indicate that teachers think a culture of cooperation would enhance STEM learning, and working with other STEM teachers and university professors is critical for creating an atmosphere to strengthen the preparation of STEM courses and demonstrating a team model for students (Asghar, Ellington, Rice, Johnson \& Prime, 2012; Bruce-Davis, Gubbins, Gilson, Villanueva, Foreman, \& Rubenstein, 2014; Herro \& Quigley, 2017; Lehman, Kim \& Harris, 2014; Stohlmann, Moore \& Roehrig, 2012). Since STEM pedagogy requires students to work together to solve challenges, it is beneficial for teachers to model the strength of a group approach. Koirala et al. (2003) believe that "middle school students benefit by seeing their teachers working in a team, because belonging to a group is very important for them" (p. 14).

Pre-service and in-service teachers' perceptions of mathematics and science integration have also been explored by several researchers (e.g., Lehman, 1994; Stevens \& Wenner, 1996). Results reveal that pre-service teachers hold positive attitudes toward integration, whereas in-service teachers show reluctance, in part due to their subject-oriented preparation (Pang et al., 2000). Obviously, teachers without basic knowledge of other disciplines can at best promote superficial connections among disciplines. Pang et al. (2000) contend that "successful implementation of integrated curricula ultimately depends on whether teachers develop a solid understanding of subject matter and conceptualize connections among subjects" (p. 77).

Some other studies explore teacher education programs designed to facilitate integrated instruction at elementary and secondary school levels (e.g., Haigh et al., 1995; Lonning \& DeFranco, 1994; Stuessy, 1995). The question is how the beginning teachers who took such integrated methods courses implement what they have learned in their daily classroom teaching and how their perceptions of integration may change. Teachers' own understanding and efforts into the integrated approach are of great significance to successful implementation and knowing teachers' perception of the integrated approach and how they apply it, in turn, has implications for the design of teacher education courses (Judson, 2013).

In-service teachers, however, face various challenges when trying to integrate content from different disciplines, including knowledge of discipline differences between subject areas (Isaacs, Wagreich, \& Gartzman, 1997; Lederman \& Lederman, 2013), lack of breadth in their own content knowledge needed for teaching in multiple subject areas (Ball, Thames, \& Phelps, 2008), dealing with time constraints (Isaacs et al., 1997), and contextual challenges (Berlin \& White, 2010; Frykholm et al., 2005) such as administrator commitment, lack of support from colleagues, major course changes or innovations (Wicklein \& Schell, 1995), 
and external testing forces aligning poorly with integrated curricula (Isaacs et al., 1997). Hence, Pang et al. (2000) call for future research to identify and explore challenges in implementing integrated curricula, ways teachers effectively address various constraints, and implications for teacher empowerment.

While the importance of integration in STEM education is increasingly emphasized and demonstrated, more often than not, teachers are not well trained to work effectively in areas dependent on multidisciplinary integration. Therefore, teachers themselves may not have experienced integration and are not well prepared to involve students in the interdisciplinary learning required by the latest national standards documents in mathematics and science within which "there is a renewed emphasis on learning the content of each discipline through engagement in an integrated educational experience, rich with opportunities to engage in disciplinary practices" (Brown \& Bogiages, 2019, p. 112).

Overall, the review of the literature indicates that policymakers, academic organizations educational administrators, educators, as well as business organizations all support and advocate the integration of mathematics and science, but due to inadequate teacher training, teachers' lack of knowledge, skill, and experience, and various factors impeding the integration, there have been quality defects in the implementation over the years. An important part of teachers' learning to implement curricula integration is for teachers to experience learning themselves through an immersive experience in the new strategy (Loucks-Horsley, Stiles, Mundry, Love \& Hewson, 2010; Brown et al., 2019). Our study thus introduces the experiences of 28 pre-service and in-service teachers during a six-week summer course on the integrated instruction of mathematics and science for $4^{\text {th }}$ and $5^{\text {th }}$ grades and explains how they made progress in knowledge, skill, and confidence in planning and teaching mathematics and science using the integrated approach. The essential role of ongoing professional development and school district administrative support in maintaining teachers' development in mathematics and science integration is also discussed.

\section{Theoretical Assumptions}

The theoretical assumptions of this study are grounded in complexity theory and social constructivism epistemology (Cobb, 1994; Cobb \& Yackel, 1996; Waldrop, 1992). The world around us operates as a complex adaptive system that exchanges energy, matter, and information with the surrounding environment. In such a complex adaptive system, long term planning is impossible. When a complex system reaches a bifurcation point, chance plays a dominant role in turning the complex system to a new road. After the road is chosen, which is unpredictable in advance, for a certain period of time, the necessity or determinism takes over until the complex system reaches another critical point. This process is not a linear or deliberative process but rather a dialectical one. This dialectical relationship between chance and necessity (determinism) exists at any given time in the life of a complex adaptive system. The potential implication of this theoretical assumption for teacher education is 
significant. Looking at the world from the lens of complexity may provide a better understanding of teachers' professional development and transformation. Teachers as complex adaptive systems must be understood through the process of their interaction and communication within their social and cultural milieu. They cannot be studied in isolation. This worldview provides a basis for understanding the nature and role of teachers' praxis (i.e. reflection and action) and is fundamental to the constructivist theory of teaching and learning. According to social constructivism, all learning and knowing is inherently social and cultural (Cobb, 1994).

\section{Context of the Study}

The current study is conducted in an American university in the Midwest. The participants include 28 pre-service and in-service teachers recruited from students enrolled in the $4^{\text {th }}$ and $5^{\text {th }}$ Generalist Endorsement Program during the first six-week session of summer 2020. All participating teachers were female. Their age ranges from 22 to 35 years. The $4^{\text {th }}$ and $5^{\text {th }}$ Generalist Endorsement is a graduate program that includes three different courses, Mathematics and Science Instruction and Assessment Grades 4-5, (three credits), Learning and Developmental course (three credits), and Integrated Social Studies and Language Arts course (three credits), totaling nine credit hours for the program. The two of these courses are taught in a blended format, combining face-to-face sessions with online interaction. The course Mathematics $\mathcal{E}$ Science Instruction $\mathcal{E}$ Assessment Grades 4-5 is taught remotely through Zoom meetings. The candidates for the program must already have a valid pre-k to 3 teaching licenses. The senior undergraduate students/pre-service teachers ( 9 participants) had already finished their studentteaching and were allowed to take the graduate course with a petition. The inservice teachers (19 participants) were early childhood majors, who earned their early childhood license for grades pre-k to 3 and had three to six years of teaching experience in early childhood school settings. They desired to build their professional credential by earning the $4^{\text {th }}$ and $5^{\text {th }}$ endorsement. Similarly, the pre-service teachers were just about to earn their pre-k through 3 license and wanted to become more marketable by earning the $4^{\text {th }}$ and $5^{\text {th }}$ endorsement. In this sense, both pre-service and in-service teachers share a common interest and purpose in taking this course.

The course is designed to extend candidates' content and pedagogy knowledge and aims to prepare $4^{\text {th }}$ and $5^{\text {th }}$ generalist teachers for the complex task of teaching mathematics and science. Teacher candidates gain experience by preparing problem-centered lessons for the $4^{\text {th }}$ and $5^{\text {th }}$ grade settings, focusing on the content and methodology appropriate for these particular groups of students. Also, during the six-week course, teacher collaboration, reflection, and constructivist theories of learning were discussed. Throughout the semester, technological tools such as Blackboard, Electronic Reserved Articles, and Films on Demand were used for instructional purposes. The participating teachers were engaged in mathematics and science activities as a basis for reflecting on learning, teaching, and assessing culturally responsive mathematics and science. In addition, they were required to develop two unit lesson plans incorporating technology for teaching mathematics and science. To accommodate all the pre- 
service and in-service teachers and make the assignments and activities meaningful and doable within the time constraints of a semester, the primary researcher paired the participating teachers to the maximum extent possible so that one pre-service teacher and one in-service teacher worked together collaboratively to fulfil their common goal of a semester-long project. Besides, each pair was required to select another pair in the classroom for critiques of their project. The reciprocal peer critiques provided the teachers with an opportunity to reflect, modify, and re-plan their lesson plans and presentations.

The instructor of the course, also the primary researcher of this study, has 25 years of teaching in this institution and had the privilege of having most of these pre-service and in-service teachers in his mathematics methods course in previous semesters or years. This prior connection and relationship with the participating teachers played a crucial role in establishing a collaborative learning community.

\section{Methodology}

This qualitative, descriptive, and interpretative study is grounded in Guba and Lincoln's $(1989 ; 1994)$ constructivist inquiry. This methodology is consistent with the theoretical assumptions of the current study. "Human behavior, unlike that of physical objects, cannot be understood without reference to the meanings and purposes attached by human actors to their activities" (Guba et al., 1994, p.106). Guba and Lincoln provided strategies for establishing trustworthiness, focusing on four criteria, namely credibility, transferability, dependability, and conformability. Credibility refers to certain activities that increase the probability that the findings will be authentic. Such activities include prolonged engagement and researchers' time investment. The second component of trustworthiness is transferability, referring to the potential for others to identify with the research context and apply the findings to their own settings, which can be achieved through "thick description". The third component is dependability which is known as the consistency of study results over time and across researchers, closely related to conformability, the fourth component of trustworthiness.

Several factors contributed to the trustworthiness of data analysis. The first factor is relative to the prior connection and professional relationship between the primary researcher and most of the participating teachers who were former students of the instructor/primary researcher in previous semesters or years. The second factor is that the instructor spent quality time with the participating teachers before and after each meeting providing them with feedback to ensure credibility criterion. In addition, the researchers had ongoing one-on-one email interactions with the participants regarding the understanding and interpretation of the data. The third factor relates to transferability, which was achieved through thick description. The fourth is relevant to dependability, which was established through the two researchers analysing the data independently and meeting once a week to exchange ideas and information. This data processing approach with active participation and feedback played a 
key role in the credibility of the research and the establishment of a supportive learning community.

Data include participating teachers' reflections on assigned readings, meeting discussions, their planning and teaching, final reflective papers, as well as the instructor's field notes. Throughout the semester there were six research articles relative to integrated mathematics and science and six Films on Demand regarding learning theories and constructivist teaching and learning. The reflections on readings and films provided a basis for meeting discussions. The participants summarized, analysed, and presented their professional opinions for each article and film weekly (one article and one film per week). Data analysis started alongside data collection using a systematic approach of iterative categorization (Neale, 2016), involving open coding (Strauss \& Corbin, 1990) which Charmaz (2001) describes as the "critical link" between data collection and meaning interpretation, inductive sorting of codes into categories based on links between codes, and moving iteratively between data and coding framework to refine codes into consistent and discrete categories. Open coding, which is referred to as vivo and descriptive codes by Saldaña (2013), was assigned to identify primary themes of the data. It allowed us to explore the understanding, practices, and reflections of the participating teachers on discipline integration. Once open coding was concluded, we moved on to the inductive sorting of codes, identifying recurrent codes, themes, metaphors, and contradictions. The data were then integrated and sorted into categories according to links between the codes. The focus was on the experiences and reflections of participating teachers in their attempts to teach mathematics and science using an integrated approach. As categories began to emerge, we went back to the participating teachers to ask them how well the ongoing data analysis represented their experience (Hays \& Singh, 2012). At the same time, we iteratively moved between data and the coding framework and refined codes into consistent and discrete categories. Along with the coding process, reflexive and analytical memos were written to "document and reflect on the coding process and code choices" (Saldaña, 2013, p. 41), which helped achieve researchers' reflexivity on the data corpus and at the same time provide documentation and transparency about our methodology. Based on the coding, we then developed a codebook to guide our report on research findings.

\section{Findings}

Data analysis revealed two attributes that contributed to the positive learning experiences of the participating teachers. The first attribute is the participating teachers' time investment in their professional development and their willingness to learn from one another. The second attribute is the instructor's role as a facilitator of the classroom discussions and activities. The instructor spent an enormous amount of time providing the teachers with timely feedback and support. As one participating teacher stated:

"Although I was not sure how to design and develop an integrated mathematics and science lesson plan, I knew and trusted my peers in the class. I was also comfortable with the instructor because I trusted him. I was sure if I asked for help, I would have plenty of support. I think that was very important for me" (The Participating Teacher's Reflection during the Class Discussion). 
From the analysis of the data including participating teachers' reflections on assigned readings, classroom discussions, teachers' planning and presentations, their final reflective papers, the instructor's field notes, and reflexive and analytical memos, the following four themes emerged:

\section{Theme 1: Importance of Integrating Mathematics and Science}

Data analysis revealed that all the 28 participating teachers believe that it is important to integrate mathematics and science. They see various reasons for the integration. First, they believe it logical for mathematics and science to be taught together. They stated that there are many aspects that mathematics and science share, making them two closely related subjects to be integrated. For example, one participating teacher shared her view this way:

"The common learning areas of mathematics and science emphasize concepts and skills that support the learning and understanding of the subjects. Integrating these subject areas makes students feel that they are no longer learning separate topics but that the content of the subject areas flows fluidly together for the whole learning goal" (The Participating Teacher's Reflection).

The participating teachers indicated that an integrated approach to learning aligns with the way the brain naturally processes and internalizes new information. Therefore, an integrated approach makes learning feel more natural. They stated that when educators begin the journey of integrating mathematics and science, they enhance the meaning of what they are teaching. As one of the participating teachers put:

"Integrated instruction provides students with an opportunity to combine academic skills from different subject areas to solve real-world problems, and this would interest and motivate students. It also allows students to become better problem solvers and logical thinkers. It has been proven that when students can relate classroom learning to real-life experiences, they are more likely to understand what is being taught and remember the information" (The Participating Teacher's Reflection).

Second, the teachers stated that an integrated approach makes students more engaged and have a desire to learn since it involves hands-on exploration and interactive activities that are engaging, fun, and intriguing. As the participating teachers worked collaboratively towards developing/designing their unit plans, they became more aware of the importance of the meaningful and challenging activities and more sensitive to their students' voices and social and cultural backgrounds. For example, one of the teachers asserted:

"Integrating mathematics and science provides the opportunity for teamwork and peer communication that can promote collaboration and communication among students, helping them learn how to combat the problems at hand by working with others. This can help all the students including English language learners (ELLs). When students work in small groups, it can be less distracting and more engaging. Besides, having the curriculum integrated also provides more opportunities for parent and community involvement" (The Participating Teacher's Reflection). 
There are several other reasons put forward by participating teachers, including improved teaching effects, transformed students' attitudes, enhanced students' interest and motivation, new mindset, and so forth. One of the teachers put it like this:

"Incorporating mathematics and science is beneficial because students can see how real-world issues revolve around science, technology, and mathematics. When math and science are taught using a student-centered approach rather than a traditional one, it is more effective and has a positive effect on students' attitudes, their interest in school, motivation to learn, and achievement of both subjects. Integration requires work from both the teacher and students who can plan and learn together to modify the instruction. It provides opportunities for students to form a deeper understanding, see the big picture, and make connections among central concepts" (The Participating Teacher's Reflection).

Another teacher shared in her reflective paper as follows:

"Integrating mathematics and science allows students to learn through selfreflection and inquiry, to increase communication with others, to challenge high-order thinking, and to transform their learning environments. Integration is a beneficial practice that prepares today's children for the future world. When teachers do this and encourage new ways of learning, they support not only their typical learners but also those have been identified as ELLs and students with disabilities; they are creating competent, well-rounded scholars, who are prepared to live and work in the global society" (The Participating Teacher's Reflection).

\section{Theme 2: Strategies for Incorporating the Integrated Approach}

Data analysis suggested that all the 28 participating teachers advocate the following six integration approaches to teaching mathematics and science. Synchronized curriculum integration refers to the way in which the common content of more than one subject is taught separately but parallel so that it is easy for teachers to build on pre-existing knowledge about a topic. Thematic curriculum integration is the way that starts with a relevant topic linking subject areas together. Students are expected to make connections around an underlying theme. The project-based approach allows integration to be built around a planned task. Students are not aware that the content of separate subjects is being taught until they make the connections themselves. Cross-curricula integration focuses on broad skills across several subject areas. Schoolspecialized integration is where the focus is rooted in the whole school curriculum, and teachers will choose and modify subjects to fit in the chosen specialization. Community-focused integration is based on meaningful issues that impact the local community, which allows students to investigate and solve a local problem using content or skills of different subject areas, thus enhancing their understanding and operational capabilities.

Data analysis also indicated that the participating teachers believe that a projectbased learning approach (PBL) would best support mathematics and science integration in a classroom due to its unique characteristics. First, PBL has students at the centre of the learning process, allowing them to have control over their own decisions and connect the new information with real-world situations. It requires students to use their inquiry skills to solve problems. Second, when supported by technology, PBL would greatly enhance students' learning 
through teamwork, improving students' collaboration and communication skills simultaneously. Third, PBL has varied instructional strategies and ongoing assessments. When students participate in PBL, they are likely to experience hands-on activities and manipulatives, which helps increase students' interest and facilitate their learning. Finally, PBL, starting with an interesting problem for students to solve and engaging students in open-ended, authentic tasks, can break the project into manageable components and yield a tangible product. One teacher shared his view like this:

"Incorporating science and mathematics with PBL is beneficial since PBL is based on real-world issues, where students can make relevant and ageappropriate connections. Effective PBL provides a unique way for students to apply their knowledge and skills and learn how to be successful in solving practical problems. Students learn because they want to, and they do not memorize information to pass a test and forget about it afterward" (The Participating Teacher's Reflection).

Another teacher presented her opinions as follows:

"The projects are created with important objectives, so students can accomplish learning goals while focusing on the subjects. Students are given models or rubrics that describe guidelines and high-quality works so that they are able to reflect, give, and receive feedback, and then adjust their work as needed" (The Participating Teacher's Reflection).

The participating teachers also proposed a variety of useful strategies for supporting ELLs in mathematics and science classrooms, including creating vocabulary banks, using group discussions and partner conversations to help ELLs verbalize their ideas, performing role-playing, using anchor charts, and so forth. Nineteen of the 28 participating teachers also stated that it is important to be aware of the factors that contribute to the success of ELLs. They shared similar views on this point:

"Knowing students' backgrounds, experiences, levels of their second language, and their challenges in learning mathematics and science is significant for teachers to build a classroom community and apply strategies that can help ELLs succeed in learning. It is essential to activate ELLs' prior knowledge, reduce their stress in the classroom, use native language as a resource, ask questions that elicit more than yes-or-no responses, provide visuals, organize small group discussions or pair work, and create hands-on and interactive activities" (The Participating Teacher's Reflection).

The participants also suggested that teachers need to pay special attention to applying differentiation strategies to support ELLs, such as making manipulatives available for them to construct physical representations of mathematics thinking, designing questions and prompts in different ways for students at different levels, and considering language and mathematics skills when grouping students.

\section{Theme 3: Participating Teachers' Experiences and Realizations in Learning}

Data analysis showed that the participating teachers had little experience of integration before taking this course, but through creating two integrated unit plans involving mathematics and science during this six-week session, all of them indicated that they learned many valuable ways to engage students by 
blurring the lines of subjects and content areas. They realized how the integration of mathematics and science may broaden student learning and expressed how they saw connections between subject areas made, which would facilitate students' deeper understanding of the materials. One teacher shared her experiences in this way:

"Before taking this course, I had very little practice in integrating subjects. I once tried integrating social studies and science during my previous teaching but found it hard because I did not have the knowledge of those approaches to integration. During this course, I created two integrated unit lesson plans involving mathematics and science and learned various ways of integrating through interaction and communication with my peers. It was interesting to see the different ways one topic is taught in different subject areas and how different but relevant topics could be integrated into one discipline" (The Participating Teacher's Reflection).

The participating teachers also shared their experiences of applying PBL in teaching, as one of them put:

"Through a project-based learning approach, students are allowed to use their skills when learning and exploring. When teaching mathematics and science using PBL, the activities can be adjusted for many different grade levels and more challenges can be added depending on the cognitive level of the class and the grade level. It is really beneficial" (The Participating Teacher's Reflection).

They also proposed some points for attention during integration. One teacher presented as follows:

"It is significant for teachers to recognize the variety of learners stepping into the classroom each day. No two children are the same and we cannot expect the same teaching style, assessment, and support to work for all the kids. We must know about our students, learn what strategies can well support their learning, and integrate that into our daily instruction. When integrating mathematics and science, it is important not to let one of the subjects dominate the class, and we must remember that manipulatives are merely tools for learning but not the goal of learning" (The Participating Teacher's Reflection).

Theme 4: Challenges and Possibilities of Implementing the Integrated Approach When indicating that they would adopt the integrated approach to their future teaching, the participating teachers also raised the challenges they expected to encounter. Data revealed that the biggest challenge is the lack of support from school administration and colleagues. The teachers mentioned that some school leaders and teachers want to keep the traditional way of teaching subjects separately instead of making changes. Issues related to school administration create severe barriers to the implementation of the integrated approach. Besides, when creating a unit plan on multiple subjects, many teachers will need to be involved and plenty of problems need to be discussed. It requires staff members to communicate and reach an agreement on how the lesson will be taught and how to make the project successful. However, it would not be possible to conduct integrated instruction when colleagues lack interest or refuse to engage. Further, integration requires a lot of planning, communication, and strong classroom management skills, so the lack of experience is the second challenge stated by the participating teachers. One of them shared her concerns as follows: 
"I am afraid that I will come up with an idea but have no support. I also fear that I will embarrass myself through failure when conducting integration. I feel that I need more help to carry out student-centered PBL because the planning must be done without knowing what students will do. I am also not sure how to set up a classroom that can allow students to learn based on their interests and experiences through 'unstructured' inquiry activities" (The Participating Teacher's Final Reflective Paper).

Other concerns of the teachers include lack of time for preparation with an already overcrowded daily schedule, the budget needed for conducting integration, and the departmentalization of different subjects in schools. Despite the varieties of challenges anticipated, all the participating teachers hold a positive attitude towards the integrated approach and are confident in the application of it in their future teaching. One teacher stated:

"Integration is a difficult task but worth the effort. Applying problem-based or project-based learning to mathematics and science lessons will promote higher levels of engagement, critical thinking, problem solving, and higher test scores of students. It is important not to have a fear of making mistakes during instruction but to learn from failures. We should believe that the barriers and obstacles can and will be overcome and a beneficial learning experience for all students and educators will be achieved with our endeavor" (The Participating Teacher's Final Reflective Paper).

Another teacher presented how she saw the future possibilities:

"Integrating mathematics and science is beneficial for both students and teachers. It can lead to a deeper understanding of both subjects. Students can learn across the curricula when the project or inquiry-based learning is used. Students learn best through integrated instruction. It needs to be implemented more in classrooms for everyday learning so that students can become handson, active, and informed lifelong learners who can apply their learning to realworld situations. I believe integrating is the best way to help students succeed in their learning and become successful in their future life" (The Participating Teacher's Final Reflective Paper).

When talking about future plans, a teacher shared:

"I hope by integrating subjects I will become a better teacher. As a future educator, I want to become more familiar with different approaches and incorporate them into my teaching. I will use the approaches depending on the characteristics of my students and the teaching styles they best adapt to. It is also important for me to research more effective strategies to help ELL students in my classroom" (The Participating Teacher's Final Reflective Paper).

\section{Discussion}

This study examined the experiences of 28 pre-service and in-service teachers as they plan and teach mathematics and science in $4^{\text {th }}$ and $5^{\text {th }}$ grades from an integrated perspective during a summer course to explain how a six-week summer course focusing on planning and teaching mathematics and science using an integrated approach enhance teachers' knowledge, experience, and confidence in curriculum integration. The findings suggest that the exchange of ideas and information with peers along with the instructor's ongoing support provides the teachers with opportunities to become more knowledgeable and 
confident in planning and teaching mathematics and science in an integrated fashion.

The six-week summer course witnessed the accumulation of knowledge and confidence of participating teachers in curriculum integration and a shift of the teachers from traditional mathematics and science instruction to the integrated approach. With little experience and confidence in the integrated approach, the participating teachers came into this class and set out on the journey of exploration with an open mind. During learning, they investigated and reflected on current research, engaged in meeting discussions, designed and created unit plans in pairs, reviewed and provided critiques to other pairs' unit plans, and completed their final reflective papers. Through this process of exploration and interaction, they identified significant issues regarding mathematics and science education, especially the teaching and learning of the two subject areas in $4^{\text {th }}$ and $5^{\text {th }}$ grade classrooms, and gradually formed their own mathematics and science teaching philosophy and goals. They began to realize that science and mathematics are more than just a set of subject areas; discipline integration is a movement to develop a deeper understanding between these content areas to make students more adaptive to the climate of uncertainties in the $21^{\text {st-century. }}$

Through their reflections and communications, the participating teachers realized that science and mathematics help develop a set of thinking, reasoning, research, collaboration, and creative skills that students can use in all areas of their lives. They became aware that integration is not a standalone class; it is a technique that intentionally incorporates different subjects into an existing curriculum. The most viable way to start is to involve students in the process of practice, and these practices enable students to relate mathematical and scientific ideas to real-world situations and apply them in everyday life. The teachers became convinced that these practices encourage students to clarify and build relationships and models among the various representations in mathematics and science.

The findings of this study also indicate that the professional collaboration and communication between pre-service and in-service teachers greatly facilitated their abilities to critically reflect on and make changes in their integrated lesson plans and instruction. The free flow of ideas and information allowed the teachers to reflect on who they are and how they can make their classroom a better learning environment for all their students. Of particular importance in the findings of this study is the role of ongoing feedback and support the teachers received from the instructor. The sense of trust that started in the sixweek summer course moved to deeper levels of communication and connection even after the course was completed. It went from knowing each other as a person to knowing each other as a professional.

The findings further reveal that ongoing professional development and support from colleagues and school administration are essential components for sustaining teachers' development in curriculum integration. No matter how deeply the teachers understand the integrated approach and how willing they 
are to apply it in their classroom to support and facilitate their students' learning, the implementation would be difficult in the absence of support from school/district and colleagues, which is the first and biggest concern raised by the participating teachers. They mentioned that some conservative school leaders are reluctant or afraid of innovation and reform in part because they do not see the potential positive impact of integration on student academic performance. This led us as researchers to think about a question: Are the existing school structures, cultures, and policies compatible with the collaborative environment needed for teacher professional transformation?

\title{
8. Conclusion
}

As Furner et al. (2007) contend, changing the way of teaching science and mathematics has always been a concern of professionals, and we should strive now to transform the teaching of science and mathematics from traditional methods to a more student-centered approach.

"It really is our obligation as an educational community to make the difference for the future of our students in an ever-growing competitive global environment, which depends so heavily on mathematics, technology, and the sciences. If schools do more in terms of integrating mathematics and the sciences, they may impact the lives of their students forever" (Furner et al., 2007, p. 188).

The quality of education teachers provide to their students highly relies on what the teachers do in the classroom. Therefore, to prepare today's students to become tomorrow's successful individuals, teachers of mathematics and science should ensure that their teaching is effective. As Bybee (1993) puts: "We certainly need books, reports, and recommendations for new policies. However, unless the classroom teachers move beyond the status quo in [mathematics] and science teaching, the reform will falter and eventually fail" ( $p$. 144). The implication of this study for teacher education is significant in terms of pedagogical knowledge and experiences relative to integrated teaching of mathematics and science. Methods courses such as the one introduced in our study play an essential role. These courses are designed to extend teachers' content and pedagogy knowledge and help improve their skills by engaging them in an immersive experience of learning new strategies, thereby enabling them to promote the development and implementation of integrated mathematics and science in their daily classroom teaching. Such problem/activity-centered courses, both exciting and academically fulfilling, can effectively enrich the practical experience of course participants.

\begin{abstract}
About the Authors:
Roland G. Pourdavood is a professor of mathematics education at Cleveland State University, Department of Teacher Education. His research interests include mathematics teachers' dialogue and reflection for transformation and school reform. In addition, he focuses on cultural diversity, socio-cultural aspects of education, and emancipatory action research for personal and social praxis.
\end{abstract}

Meng Yan is a doctoral candidate in urban education at Cleveland State University. Her current research interests include curriculum development and instruction, teaching effectiveness, student motivation, parenting style and 
student well-being. She is also interested in second language acquisition, bilingualism, and the relationship between language and thought.

\section{References}

Adams, T. L. (1998). Prospective elementary teachers' mathematics subject matter knowledge: The real number system. Action in Teacher Education, 20(2), 35-48. https://doi.org/10.1080/01626620.1998.10462915

American Association for the Advancement of Science. AAAS. (1993). Benchmarks for science literacy. Oxford University Press.

Asghar, A., Ellington, R., Rice, E., Johnson, F., \& Prime, G. M. (2012). Supporting STEM education in secondary science contexts. Interdisciplinary Journal of Problem-Based Learning, 6(2), 4. https://doi.org/10.7771/1541-5015.1349

Babbitt, B. C., \& Van Vactor, J. C. (1993). A case study of mathematics learning disability in a prospective teacher. Focus on Learning Problems in Mathematics, 15(1), 23-37.

Ball, D. L. (1991). Research on teaching mathematics: Making subject matter knowledge part of the equation. In J. Brophy (Ed.), Advances in research on teaching: Teachers' subject matter knowledge and classroom instruction (Vol. 2, pp. 1- 48). JAI Press.

Ball, D. L., Thames, M. H., \& Phelps, G. (2008). Content knowledge for teaching: What makes it special. Journal of Teacher Education, 59(5), 389-407. https:// doi.org/10.1177/0022487108324554

Basista, B., \& Mathews, S. (2002). Integrated science and mathematics professional development programs. The School of Science and Mathematics, 102(7), 359-370. https://doi.org/10.1111/j.1949-8594.2002.tb18219.x

Berlin, D. F., \& Lee, H. (2005). Integrating science and mathematics education: Historical analysis. School Science and Mathematics, 105(1), 15-24. https://doi.org/10.1111/j.1949-8594.2005.tb18032.x

Berlin, D. F., \& White, A. L. (1995). Connecting school science and mathematics. Connecting Mathematics across the Curriculum, 22-33.

Berlin, D. F., \& White, A. L. (2010). Preservice mathematics and science teachers in an integrated teacher preparation program for grades 7-12: A 3-year study of attitudes and perceptions related to integration. International Journal of Science and Mathematics Education, 8(1), 97-115. https://doi.org/10.1007/s10763-0099164-0

Bossé, M. J., Lee, T. D., Swinson, M., \& Faulconer, J. (2010). The NCTM process standards and the five Es of science: Connecting math and science. School Science and Mathematics, 110(5), 262-276. https:// doi.org/10.1111/j.1949-8594.2010.00033.x

Bragow, D., Gragow, K. A., \& Smith, E. (1995). Back to the future: Toward curriculum integration. Middle School Journal, 27(2), 39-46. https://doi.org/10.1080/00940771.1995.11496152

Brown, R. E., \& Bogiages, C. A. (2019). Professional development through STEM integration: How early career math and science teachers respond to experiencing integrated STEM tasks. International Journal of Science and Mathematics Education, 17(1), 111-128. https:// doi.org/10.1007/s10763-017-9863-x

Bruce-Davis, M. N., Gubbins, E. J., Gilson, C. M., Villanueva, M., Foreman, J. L., \& Rubenstein, L. D. (2014). STEM high school administrators', teachers', and students' perceptions of curricular and instructional strategies and practices. Journal of Advanced Academics, 25(3), 272-306. https://doi.org/10.1177/1932202x14527952

Bybee, R. W. (1993). Reforming science education: Social perspectives \& personal reflections. Teachers College Press. 
Caprile, M., Palmén, R., Sanz, P., \& Dente, G. (2015). Encouraging STEM studies labor market situation and comparison of practices targeted at young people in different member states. Policy Department A.

Charette, R. N. (2013). The STEM crisis is a myth. IEEE Spectrum, 50(9), 44-59. https://doi.org/10.1109/mspec.2013.6587189

Charmaz, K. (2001). Grounded theory: Methodology and theory construction. https:// doi.org/10.1016/b0-08-043076-7/00775-0

Christenson, J. (2011). Ramaley coined STEM term now used nationwide. Minona Daily News. https://www.winonadailynews.com/news/local/ramaley-coined-stemterm-now-usednationwide/article_457afe3e-0db3-11e1-abe0-001cc4c03286.html

Cobb, P. (1994). Where is mind? Constructivist and sociocultural perspectives on mathematical development. Educational Researcher, 23(7), 13-20. https://doi.org/10.3102/0013189x023007013

Cobb, P., \& Yachel, E. (1996). Constructivist, emergent, and sociocultural perspectives in the context of developmental research. Educational Psychologist, 31(3), 175-190. https://doi.org/10.1207/s15326985ep3103\&4_3

Czerniak, C. M., Weber Jr, W. B., Sandmann, A., \& Ahern, J. (1999). A literature review of science and mathematics integration. School Science and Mathematics, 99(8), 421430. https://doi.org/10.1111/j.1949-8594.1999.tb17504.x

Davison, D. M., Miller, K. W., \& Metheny, D. L. (1995). What does integration of science and mathematics really mean?. School Science and Mathematics, 95(5), 226-230. https://doi.org/10.1111/j.1949-8594.1995.tb15771.x

Drake, S. M., (2000). Curriculum Handbook: Integrated curriculum. ASCD. http://www.ascd.org/publications/curriculumhandbook/425/chapters/Overview.aspx

Education Development Centre. IPS Group. (1969). College introductory physical science. Prentice Hall.

English, L. D. (2016). STEM education K-12: Perspectives on integration. International Journal of STEM education, 3(1), 3. https:// doi.org/10.1186/s40594-016-0036-1

English, L. D. (2017). Advancing elementary and middle school STEM education. International Journal of Science and Mathematics Education, 15(1), 5-24. https://doi.org/10.1007/s10763-017-9802-x

Frykholm, J., \& Glasson, G. (2005). Connecting science and mathematics instruction: Pedagogical context knowledge for teachers. School Science and Mathematics, 105(3), 127-141. https://doi.org/10.1111/j.1949-8594.2005.tb18047.x

Furner, J. M., \& Kumar, D. D. (2007). The mathematics and science integration argument: A stand for teacher education. Eurasia Journal of Mathematics, Science and Technology Education, 3(3), 185-189. https://doi.org/10.12973/ ejmste/75397

Gomez, A., \& Albrecht, B. (2013). True STEM education. Technology and Engineering Teacher, 73(4), 8-16.

Guba, E. G., \& Lincoln, Y. S. (1989). Fourth generation evaluation. Newbury Park, CA: Sage.

Guba, E. G., \& Lincoln, Y. S. (1994). Comparing paradigm in qualitative research. In N. K. Denzin \& Y. S. Lincoln (Eds.), Handbook of qualitative research (pp. 105-117). Thousand Oaks, CA: Sage.

Guthrie, J. T., Wigfield, A., \& VonSecker, C. (2000). Effects of integrated instruction on motivation and strategy use in reading. Journal of educational psychology, 92(2), 331-341. https:// doi.org/10.1037/0022-0663.92.2.331

Haigh, W. E. (1985). Improvement of under prepared mathematics and science teachers. Washington, D.C.: National Science Foundation. 
Haigh, W., \& Rehfeld, D. (1995). Integration of secondary mathematics and science methods courses: A model. School Science and Mathematics, 95(5), 240-247. https://doi.org/10.1111/j.1949-8594.1995.tb15774.x

Hays, D. G., \& Singh, A. A. (2012). Qualitative inquiry in clinical and educational settings. The Guilford Press.

Herro, D., \& Quigley, C. (2017). Exploring teachers' perceptions of STEAM teaching through professional development: implications for teacher educators. Professional Development in Education, 43(3), 416-438. https:// doi.org/10.1080/19415257.2016.1205507

Honey, M., Pearson, G., \& Schweingruber, H. A. (Eds.). (2014). STEM integration in K-12 education: Status, prospects, and an agenda for research (Vol. 500). National Academies Press.

Hopkins, S., Forgasz, H., Corrigan, D., \& Panizzon, D. (2014, July 12-15). The STEM issue in Australia: What it is and where is the evidence. STEM Conference: STEM Education and Our Planet: Making Connections Across Contexts [Conference presentation]. Vancouver, Canada. https://stem2014.ubc.ca/

Huntley, M. A. (1998). Design and implementation of a framework for defining integrated mathematics and science education. School Science and Mathematics, 98(6), 320-327. https://doi.org/10.1111/j.1949-8594.1998.tb17427.x

Hurley, M. M. (2001). Reviewing integrated science and mathematics: The search for evidence and definitions from new perspectives. School Science and Mathematics, 101(5), 259-268. https://doi.org/10.1111/j.1949-8594.2001.tb18028.x

Isaacs, A., Wagreich, P., \& Gartzman, M. (1997). The quest for integration: School mathematics and science. American Journal of Education, 106(1), 179-206. https://doi.org/10.1086/444180

Johnson. C. C., Mohr-Schoeder, M. J., Moore, T. J., \& English, L. D. (2020). Handbook of research on STEM education. Taylor \& Francis Publishing.

Judson, E. (2013). Development of an instrument to assess and deliberate on the integration of mathematics into student-centered science learning. School Science and Mathematics, 113(2), 56-68. https://doi.org/10.1111/ssm.12004

Koirala, H. P., \& Bowman, J. K. (2003). Preparing middle level preservice teachers to integrate mathematics and science: Problems and possibilities. School Science and Mathematics, 103(3), 145-154. https:// doi.org/10.1111/j.1949-8594.2003.tb18231.x

Kruger, C. (1990). Some primary teachers' ideas about energy. Physics Education, 25(2), 86-91. https://doi.org/10.1088/0031-9120/25/2/002

Lederman, N. G., \& Lederman, J. S. (2013). Is it STEM or "S \& M" that we truly love?. Journal of Science Teacher Education, 24(8), 1237-1240. https:// doi.org/10.1007/s10972-013-9370-z

Lederman, N. G., \& Niess, M. L. (1997). Integrated, interdisciplinary, or thematic instruction? Is this a question or is it questionable semantics?. School Science and Mathematics, 97(2), 57.

Lehman, J. R. (1994). Integrating science and mathematics: Perceptions of preservice and practicing elementary teachers. School Science and Mathematics, 94(2), 58- 64. https://doi.org/10.1111/j.1949-8594.1994.tb12293.x

Lehman, J., Kim, W., \& Harris, C. (2014). Collaborations in a community of practice working to integrate engineering design in elementary science education. Journal of STEM Education, 15(3).

Lonning, R. A., \& DeFranco, T. C. (1994). Development and implementation of an integrated mathematics/science preservice elementary methods course. School Science and Mathematics, 94(1), 18-25. https://doi.org/10.1111/j.19498594.1994.tb12284.x 
Lonning, R. A., \& DeFranco, T. C. (1997). Integration of science and mathematics: A theoretical model. School Science and Mathematics, 97(4), 212-215. https://doi.org/10.1111/j.1949-8594.1997.tb17369.x

Loucks-Horsley, S., Stiles, K., Mundry, S., Love, N., \& Hewson, P. (2010). Designing professional development for teachers of science and mathematics. Sage Publication.

Marginson, S., Tytler, R., Freeman, B., \& Roberts, K. (2013). STEM: country comparisons: international comparisons of science, technology, engineering and mathematics (STEM) education. Final report.

Margot, K. C., \& Kettler, T. (2019). Teachers' perception of STEM integration and education: a systematic literature review. International Journal of STEM Education, 6(1), 2. https://doi.org/10.1186/s40594-018-0151-2

Masters, G. (2016). Policy insights: Five challenges in Australian school education. Australian Council for Educational Research.

McComas, W. F. (1993). STS education and the affective domain. What Research Says to the Science Teacher, 7, 161-168.

Moore, T. J., Glancy, A. W., Tank, K. M., Kersten, J. A., Smith, K. A., \& Stohlmann, M. S. (2014). A framework for quality K-12 engineering education: Research and development. Journal of Pre-College Engineering Education Research (J-PEER), 4(1), 2. https://doi.org/10.7771/2157-9288.1069

National Council of Teachers of Mathematics. (2000). Principles and standards for school mathematics. Reston, VA: National Council of Teachers of Mathematics.

National Research Council. (1996). National science education standards. The National Academies Press.

Neale, J. (2016). Iterative categorization (IC): A systematic technique for analysing qualitative data. Addiction, 111(6), 1096-1106. https://doi.org/10.1111/add.13314

Pang, J., \& Good, R. (2000). A review of the integration of science and mathematics: Implications for further research. School Science and Mathematics, 100(2), 73-82. https://doi.org/10.1111/j.1949-8594.2000.tb17239.x

Penprase, B. (2020). STEM education for 21st century. Springer International Publishing. https://doi.org/10.1007/978-3-030-41633-1

Prinsley, R., \& Baranyai, K. (2015). STEM-trained and job-ready. Office of the Chief Scientist, 12, 1-4.

Pyke, C. L., \& Lynch, S. (2005). Mathematics and science teachers' preparation for National Board of Professional Teaching Standards certification. School Science and Mathematics, 105(1), 25-35. https://doi.org/10.1111/j.19498594.2005.tb18033.x

Ríordáin, M. N., Johnston, J., \& Walshe, G. (2016). Making mathematics and science integration happen: Key aspects of practice. International journal of mathematical education in science and technology, 47(2), 233-255. https://doi.org/10.1080/0020739x.2015.1078001

Saldaña, J. (2013). The coding manual for qualitative researchers (2nd Ed.). SAGE Publications.

Shaughnessy, J. M. (2013). Mathematics in a STEM context. Mathematics Teaching in the Middle school, 18(6), 324-324. https://doi.org/10.5951/mathteacmiddscho.18.6.0324

STEM Task Force Report. (2014). Innovate: A blueprint for science, technology, engineering, and mathematics in California public education. Californians Dedicated to Education Foundation. 
Stevens, C., \& Wenner, G. (1996). Elementary pre-service teachers' knowledge and beliefs regarding science and mathematics. School Science and Mathematics, 96(1), 2-9. https://doi.org/10.1111/j.1949-8594.1996.tb10204.x

Stohlmann, M., Moore, T. J., \& Roehrig, G. H. (2012). Considerations for teaching integrated STEM education. Journal of Pre-College Engineering Education Research (J-PEER), 2(1), 28-34. https:/ / doi.org/10.5703/1288284314653

Strauss, A., \& Corbin, J. (1990). Basics of qualitative research: Grounded theory procedures and techniques. Thousand Oaks, CA: Sage.

Stuessy, C. L. (1995). Invited comments: A model for preservice teacher preparation that integrates the teaching and learning of mathematics and science. School Science and Mathematics, 94(1), 30-31. https://doi.org/10.1111/j.19498594.1994.tb12286.x

Treacy, P., \& O'Donoghue, J. (2013). Authentic integration: A model for integrating mathematics and science in the classroom. International Journal of Mathematical Education in Science and Technology, 45(5), 703-718. https:// doi.org/10.1080/0020739x.2013.868543

Underbill, R. G. (1995). Integrating math and science: We need dialogue! School Science and Mathematics, 95(5), 225-255. https://doi.org/10.1111/j.19498594.1995.tb15770.x

Utley, J., Moseley, C., \& Bryant, R. (2005). Relationship between science and mathematics teaching efficacy of preservice elementary teachers. School Science and Mathematics, 105(2), 82-87. https://doi.org/10.1111/j.1949-8594.2005.tb18040.x

Waldrop, M. M. (1992). Complexity: The emerging science at the edge of order and chaos. Simon \& Schuster.

West, S. S., Vasquez-Mireles, S., \& Coker, C. (2006). Mathematics and/or science education: Separate or integrate. Journal of Mathematical Sciences and Mathematics Education, 1(2), 11-18.

Wicklein, R. C., \& Schell, J. W. (1995). Case studies of multidisciplinary approaches to integrating mathematics, science and technology education. Journal of Technology Education, 6(2), 59-76. https://doi.org/10.21061/jte.v6i2.a.5 